\title{
Effect of the aqueous extract of Senecio biafrae (Oliv. \& Hiern) J. Moore on sexual maturation of immature female rat
}

\author{
Landry L Lienou', Bruno P Telefo ${ }^{1 *}$, Bayala Bale², Didiane Yemele', Richard S Tagne ${ }^{1}$, Stephanie C Goka', \\ Chantal M Lemfack', Celestin Mouokeu ${ }^{1}$ and Paul F Moundipa ${ }^{3}$
}

\begin{abstract}
Background: Senecio biafrae (Asteraceae) is a medicinal plant widely used by traditional healers in the western region of Cameroon for the treatment of female infertility. This experiment was designed to evaluate the effect of the aqueous extract from leaves and stems of $\mathrm{S}$. biafrae (AESb) on the onset of puberty and some biochemical and physiological parameters of reproduction in immature Wistar female rats.

Methods: Different doses of AESb were daily and orally administered to immature female rats (13 animals/group) for 30 days. At the end of the treatment period, six animal of each experimental group were sacrificed and their body, ovarian, uterus weight; uterine, ovarian protein or cholesterol level as well as data on puberty onset recorded. The remaining animals of each group were used for the fertility test and some gestational parameters recorded.
\end{abstract}

Results: A linear increase in the growth rate of all animals was observed. The body weight gain in animals treated at the dose of $8 \mathrm{mg} / \mathrm{kg}$ of AESb significantly increased $(p<0.05)$ after 25 days of treatment while those receiving the doses of 32 and $64 \mathrm{mg} / \mathrm{kg}$ presented a significantly low body weight gain starting from the $19^{\text {th }}$ day till the end of the treatment period. The ages (days) of animals at vaginal opening $(\mathrm{VO})$ was significantly reduced ( $p<$ $0.05)$ in those treated with the doses of $32(41.25 \pm 0.51)$ and $64 \mathrm{mg} / \mathrm{kg}(41.42 \pm 0.54)$ as compared to control animals $(43.33 \pm 0.73)$. AESb significantly increased $(p<0.05)$ the ovarian weight and the number of corpora lutea in animals treated with $8 \mathrm{mg} / \mathrm{kg}$ as well as the uterine weight and protein levels irrespective of the dose. No significant effect of the extract on various fertility and gestational parameters was registered.

Conclusion: The overall results of the present study provide evidence on the puberty onset induction and ovarian folliculogenesis effect of AESb in immature female rat.

\section{Background}

Medicinal Plants have been used for many years in daily life to treat diseases all over the world [1,2]. According to the World Health Organization (WHO), more than three-quarters of the world's population rely upon complementary and alternative medicine for health care [3]. Many medicinal plants are used to treat various reproductive function ailments such as female infertility which is a public health concern in Sub-Saharan African

\footnotetext{
* Correspondence: bphelix@yahoo.co.uk

'University of Dschang, Faculty of Science, Department of Biochemistry, P.O Box: 67 Dschang, Cameroon

Full list of author information is available at the end of the article
}

countries [4]. Senecio biafrae (Oliv. \& Hiern) J. Moore (Asteraceae) (syns. Crassocephalum biafrae and Solanecio biafrae) is one of these plants [5]. It is a perennial climbing herb which naturally occurs in African forest zones, from Guinea to Uganda. Its leaves contain various secondary metabolites such as dihydroisocoumarins, terpenoids, sesquiterpenes or amino acids [6-8]. Senecio biafrae is equally known for its therapeutic virtues, notably in Nigeria where it is used in the treatment of diabetes or pulmonary defects [9-11]. In Benin, Côte d'Ivoire, Congo, or Cameroon it is used in traditional medicine to treat many diseases such as bleeding from cuts, sore eyes, cough, heart troubles, rheumatic pain, or

\section{Biomed Central}


localized oedemas [6]. In the Western and North-western Regions of Cameroon, ethnobotanical studies revealed its utilization in the treatment of cases of women infertility $[5,12]$.

Many conditions can be associated to infertility, among which non avoidable factors (anatomic, genetic, hormonal and immunological problems) and avoidable factors such as Sexually Transmitted Infections (STI), infections after parturition or surgery, tuberculosis of the pelvis, and obesity $[13,14]$. A range of medical and alternative treatments exist for infertility. They include the use of fertility drugs to stimulate "superovulation", intrauterine insemination, Assisted Reproductive Technologies (ARTs) and medicinal plants preparation to which most of the infertile couple in developing countries generally rely for their treatment $[15,16]$.

Many studies have indicated the implication of secondary metabolites from medicinal plants on the regulation of reproductive functions [17-21]. These metabolites act on main organs of the reproductive system to inhibit or induce ovarian folliculogenesis. Their biological activities are often evaluated on reproductive organs of immature female rats which have long been used as a model system for studying, in vivo, the inducing effect of pharmacological compounds $[22,23]$ and medicinal plants $[18,24,25]$ on ovarian folliculogenesis. In those various studies, the gonadotrophic-like effects of the preparation was characterized by the following biological parameters: increase in the weight of the ovary and uterus; opening and cornification of the vagina; formation of corpora lutea or changes in the histology of the ovary, uterus and vagina; induction of ovulation; increase in ovarian estradiol, progesterone, protein levels; decrease in ovarian cholesterol level.

The leaves and stems of Senecio biafrae are used either macerated in water or in palm wine by traditional healers of our locality to treat cases of women infertility [5]. Our previous studies on the effect of its ethanolic extract on some physiological parameters of reproduction showed an increase in ovarian or uteri weights and proteins as well as an acceleration of the onset of puberty in immature female rats [26]. The present study therefore aimed at evaluating the effect of the aqueous extract of S. biafrae (AESb) on similar parameters of sexual maturation (puberty onset, fertility induction) in immature female rat. The precocity of the puberty onset in treated animals was evaluated through the determination of their age at vaginal opening and the inducing effect of the extract on animal fertility evaluated through the determination of ovarian and uterine weights, protein or cholesterol levels; number of corpora lutea, implantation sites and other gestational parameters.

\section{Methods}

\section{Preparation of the extract}

The fresh leaves and stems of S. biafrae were collected in May 2010 in Baham subdivision (Western Region of Cameroon) and identified at the National Herbarium of Cameroon under voucher specimen code 32999/SRF/ Cam. These plant parts were washed and dried at room temperature. The dried plants were ground in a mortar and the powder obtained used to prepare the aqueous extract by maceration in distilled water for $24 \mathrm{~h}$. At the end of this period, the solution was filtered before being dried in a ventilated oven at $45^{\circ} \mathrm{C}$. The dry powder was weighed and stored at $4^{\circ} \mathrm{C}$ in a refrigerator. The yield of extraction was $16.6 \%$. The extracts were prepared in distilled water at concentrations of $2.8 \mathrm{mg} / \mathrm{ml}$ (extract 1 ), $11.2 \mathrm{mg} / \mathrm{ml}$ (extract 2) and $22.4 \mathrm{mg} / \mathrm{ml}$ (extract 3 ). Together with distilled water (control group), these preparations (extracts 1, 2 and 3) were orally administered to animals in a volume of $3 \mathrm{ml} / \mathrm{kg}$ body weight, corresponding to doses of $0,8,32$, and $64 \mathrm{mg} / \mathrm{kg}$ respectively. The dose of $8 \mathrm{mg} / \mathrm{kg}$ was reconstituted on the basis of information from traditional medicine practitioners in an ethnopharmacological survey performed in Baham subdivision (Western Region of Cameroon), and the two other doses (32 and $64 \mathrm{mg} / \mathrm{kg}$ ) were its multiples

\section{Animals}

The animals used in this study were immature female albino Wistar rats, 21-22 days old, weighing 30-45 g. They were bred in the animal house of the Biochemistry Department (University of Dschang, Cameroon), housed under natural conditions of light (12 h cycle) and temperature $\left(22 \pm 2^{\circ} \mathrm{C}\right)$ and fed with a standard laboratory diet and tap water ad libitum.

\section{Ethical consideration}

Experimental protocols used in this study strictly conformed with the internationally accepted standard ethical guidelines for laboratory animal use and care as described in the European Community guidelines; EEC Directive 86/609/EEC, of the 24th November 1986 [27].

\section{Puberty onset and fertility assays}

A total of fifty-two immature female rats were randomized, based on their body weight, into 4 groups of thirteen animals each. They received by gavage, either distilled water or different doses of AESb for 30 consecutive days. Their body weight and food intake were recorded, throughout the experimental period, at 2 day intervals. After two weeks of treatment, each rat was checked every day for vaginal opening and the vaginal smear collected and stained from the day of opening up to the end of the experiment. The vaginal smears were stained by May-Grünwald solution ( $1 \% \mathrm{w} / \mathrm{v})$ followed by 
Giemsa solution (1\%w/v) and viewed under low magnification $(40 \times)$ under a light microscope. This staining helped in characterizing each phase of the rat's estrous cycle, its length and that of the complete cycle. At the end of the experimental period, 6 animals in each group were randomly sacrificed by anesthesia using chloroform. Their ovaries and uteri were removed, blotted, weighed and stored at $-20^{\circ} \mathrm{C}$ until use.

The remaining rats (7 per group) were crossed the following day, during two weeks, with males of proven fertility. Vaginal smears were collected on a daily basis in order to assess for the presence of sperm. A laparoscopy was undertaken under diazepam $(5 \mathrm{mg} / \mathrm{ml}, 5 \mathrm{mg} / \mathrm{kg})$ and Ketamin $(50 \mathrm{mg} / \mathrm{ml}, 80 \mathrm{mg} / \mathrm{kg}$ ) ten days after the day of mating to count the number of implantation sites in uterine cords and the number of corpora lutea in ovaries. After delivery, the fetuses were weighed and their number recorded. From these data, the number of resorption sites (number of implantation site - number of live fetuses), implantation index ([total number of implantation sites/number corpora lutea] $\times 100)$, resorption index ([total number of resorption sites/total number of implantation sites] $\times 100)$, preimplantation loss ([number of corpora lutea - number of implantations/ number of corpora lutea] $\times 100)$, postimplantation loss ([number of implantations $\times$ number of life fetuses/ number of implantations] $\times 100)$, antifertility activity ([number of females without life fetuses/total number of females] $\times 100$ ), antiimplantation activity ([number of females without implantation sites/total number of females] $\times 100$ ), and gestation rate ([number of females with life fetuses at birth/total number of gestational females] $\times 100)$ were calculated [28].

\section{Preparation of the uterine and ovarian supernatants and biochemical analysis}

Ovaries and uteri were homogenized in Tris - sucrose buffer $(0.25 \mathrm{M}$ sucrose, $1 \mathrm{mM}$ EDTA and $10 \mathrm{mM}$ Tris$\mathrm{HCl}, \mathrm{pH} 7.4)$ at $1 \%$ and $2 \%$ respectively. The homogenate was then centrifuged at $6000 \times g$ at $4^{\circ} \mathrm{C}$ (Beckman model J2-21) for $15 \mathrm{~min}$, and the supernatants collected were used for protein [29] and cholesterol [30-32] assays.

\section{Statistical analysis}

The data from biological assays were treated by the one way Analysis of Variance (ANOVA) test and presented as Mean \pm SEM (standard error on the mean). The Fisher PLSD test was used for the comparison of means. The analysis of percentages was done by $\mathrm{X}^{2}$ (Chisquare) test. The Kruskall-Wallis test was used for non parametrical data, and the Mann Whitney test used when their differences were significant [33].

\section{Results}

Effect of AESb on body weight gain and food intake

The effect of AESb on the body weight of female rats during the treatment is presented in Figure 1. There was a linear increase, at various rates, in their growth. Compared to control animals, a significant drop in the body weight of animals treated with the doses of 32 and $64 \mathrm{mg} / \mathrm{kg}$ was indeed noticed after 19 days of treatment. Animals receiving the $8 \mathrm{mg} / \mathrm{kg}$ dose instead gained more weight $(\mathrm{p}<0.05)$ compared to control animals, starting from the 25th day of treatment till the end of the experiment. As concerns the monitoring of their food intake, no significant variation, whatever the duration of the treatment, was observed between the different experimental groups (Figure 2).

\section{Effect of AESb on the age and estrous cycle phases at vaginal opening}

Figure 3 shows the mean age of animals at vaginal opening and the percentage of those presenting vaginal aperture at a given age. Female rats that received AESb at the two highest doses presented vaginal opening almost two days earlier $(\mathrm{p}<0.05)$ as compared to the control animals $[43.33 \pm 0.73$ days $(0 \mathrm{mg} / \mathrm{kg})$ vs $41.25 \pm 0.51$ days $(32 \mathrm{mg} / \mathrm{kg})$ or $41.42 \pm 0.54$ days $(64 \mathrm{mg} / \mathrm{kg})]$. About $8 \%$ of 38 days old rats treated at $32 \mathrm{mg} / \mathrm{kg}$ (against 0\% for its respective control) presented vaginal aperture. This percentage was significantly increased in these animals and in those treated at $64 \mathrm{mg} / \mathrm{kg}$ dose when they were 42 or 43 days old ( $92 \%$ with the two doses compared to $48 \%$ with $0 \mathrm{mg} / \mathrm{kg}$ ). Moreover, complete vaginal opening was obtained in all animals of these experimental groups (32 and $64 \mathrm{mg} / \mathrm{kg}$ ) when they were 45 or 46 days old, contrary to those of the control group for which it was obtained at the age of 50. Most of these animals presented an estrus $(23 \%-46 \%)$ or metoestrus $(8 \%-46 \%)$ vaginal cycle phase on the day of their vaginal opening (Table 1).

\section{Effect of AESb on the estrous cycle length}

No changes in the estrous cycle length of animals of various experimental groups as well as in the duration of the estrus, metestrus and diestrus phases of their cycle were observed (Table 2). However, a slight decrease in the duration of the proestrus phase of animals treated at the dose of 8 and $32 \mathrm{mg} / \mathrm{kg}$ was recorded.

\section{Effect of AESb on ovarian weight, protein or cholesterol level and corpora lutea number}

The changes obtained in ovaries after 30 days of oral administration of various doses of AESb to immature rats are presented in Figure 4. No significant variations 


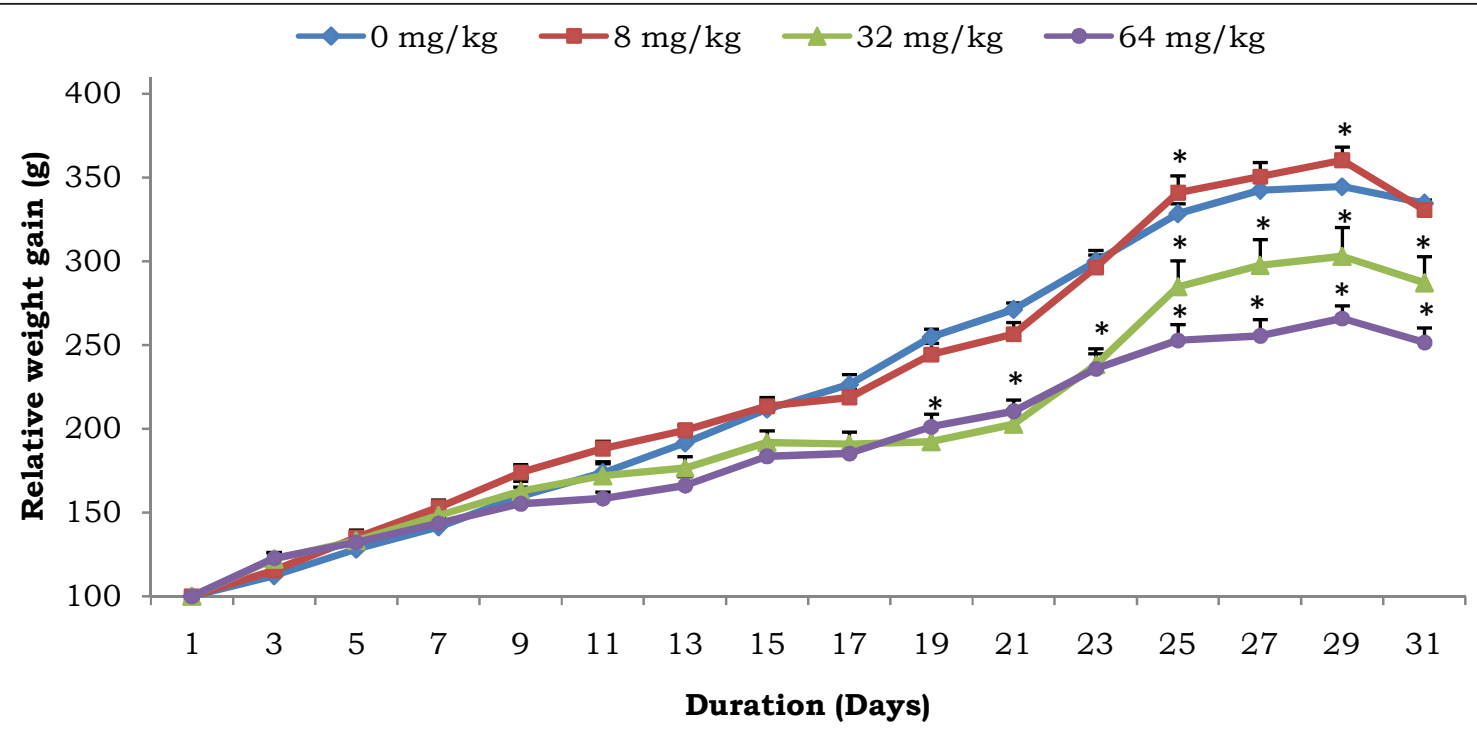

Figure 1 Body weight gain of rats after administration of various doses of AESb. Each point represents mean \pm SEM of 13 animals per group. *Values statistically different from that of the control group of each day at $\mathrm{P}<0.05$ (ANOVA and Fisher PLSD).

in ovarian cholesterol and protein levels were recorded (data not shown). When administered at the dose of 8 $\mathrm{mg} / \mathrm{kg}$ and in comparison to the control group, the extract significantly increased $(\mathrm{P}<0.05)$ the number of corpora lutea, and the relative weight of ovaries (Figure $4 \mathrm{~A}$ and $4 \mathrm{~B})$.

\section{Effect of AESb on uterine weight and proteins}

Oral administration of AESb to immature female rats significantly increased the weight of their uteri irrespective the dose administered (Figure 5A). Uterine proteins were also increased in these animals notably by two ( 8 $\mathrm{mg} / \mathrm{kg}$ ) to three fold (32 and $64 \mathrm{mg} / \mathrm{kg} ; \mathrm{P}<0.01$ ) (Figure 5B).

\section{Effect of AESb on some fertility and gestational parameters}

Table 3 shows that oral administration of AESb at doses of 8,32 and $64 \mathrm{mg} / \mathrm{kg}$ showed no significant effect on the number of pregnant rats, implantation sites and fetal weight. However, a slight increase in the number of resorption sites at the dose of $64 \mathrm{mg} / \mathrm{kg}$ was obtained. This resulted in antiimplantation and antifertility activities of $14 \%$ and $29 \%$ respectively.

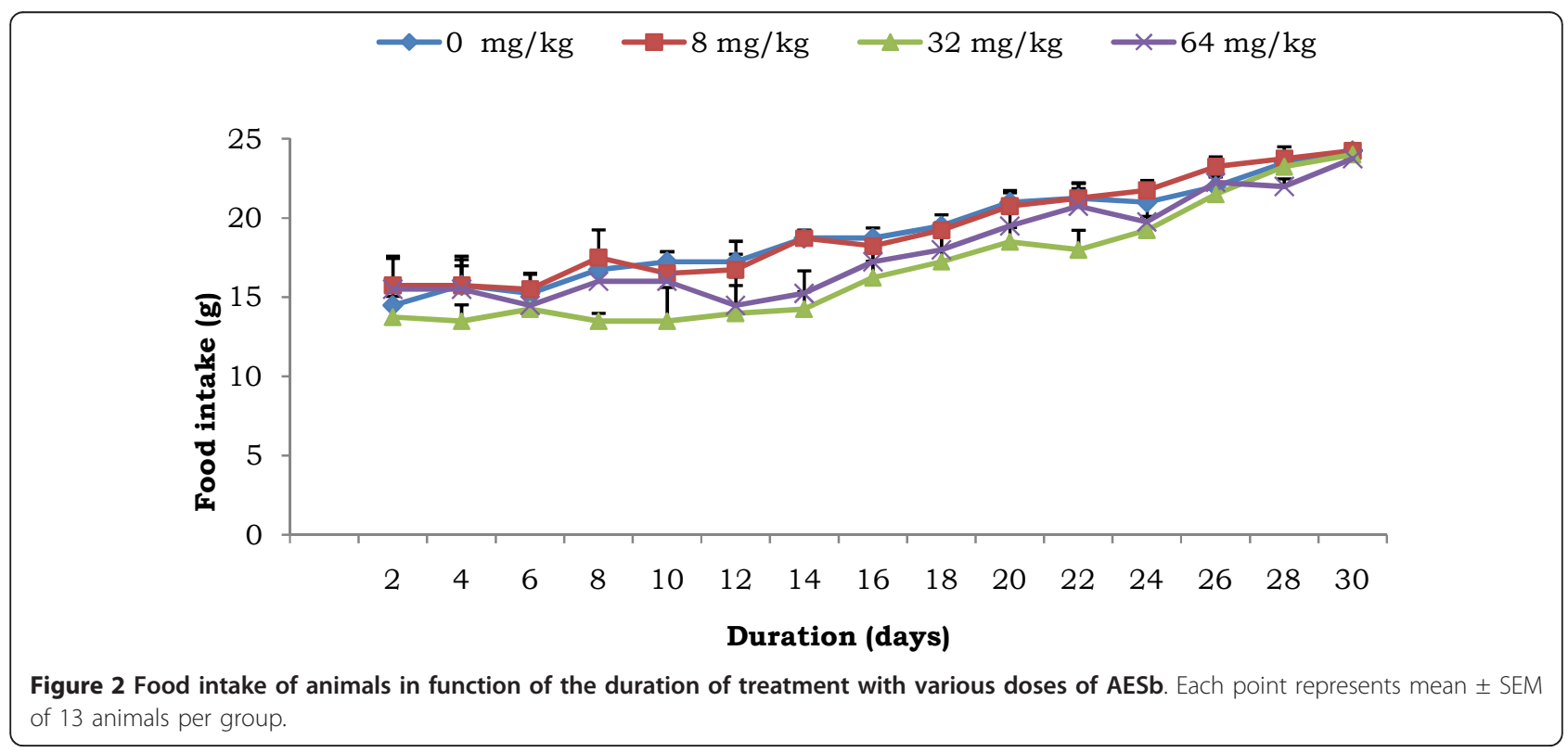




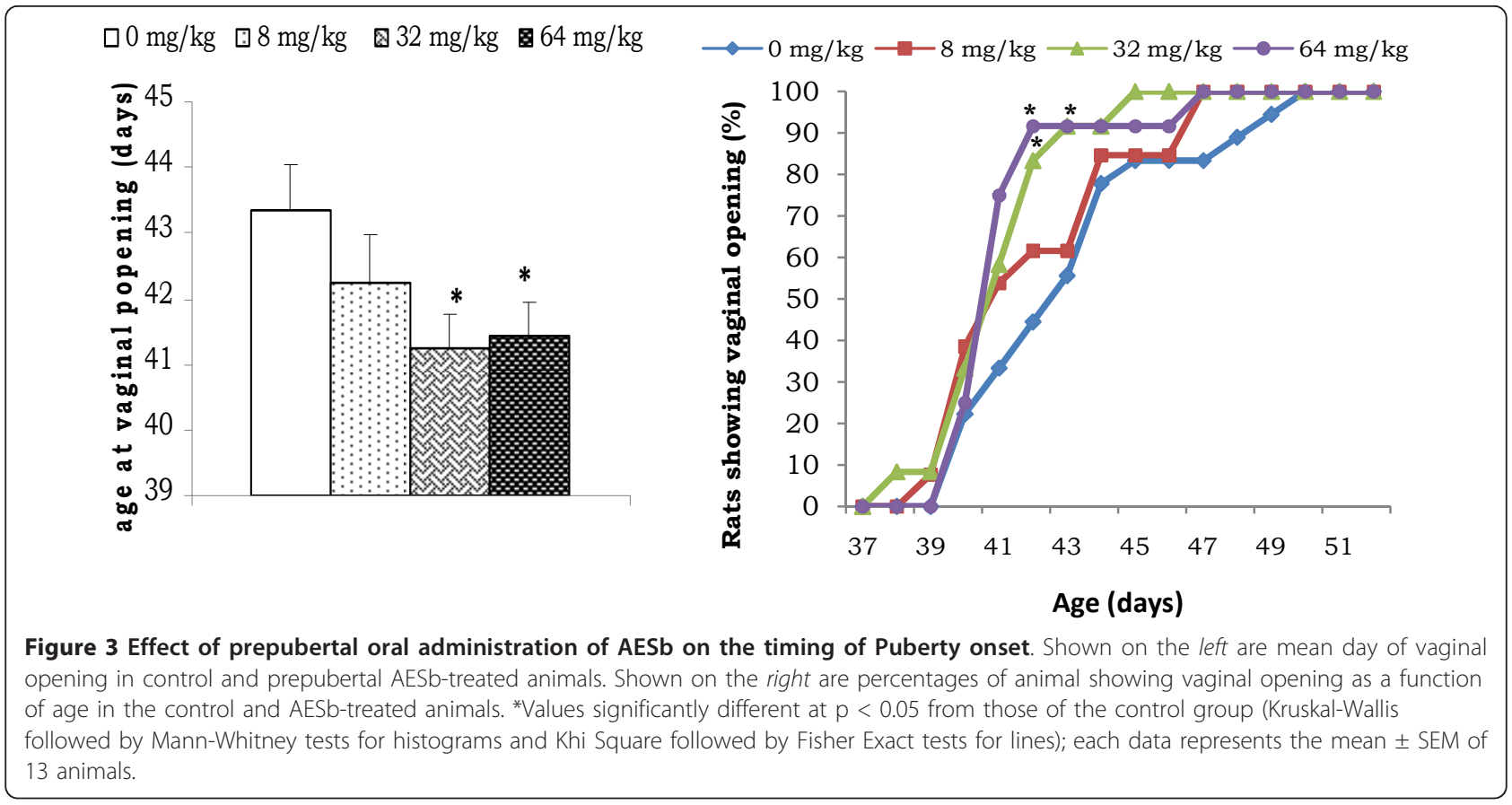

\section{Discussion}

Senecio biafrae, which is the plant of interest in this study, is used by some people in Africa for its nutritional and pharmacological properties [6,7,9-11]. Its effect on the onset of puberty (age and phase of the estrous cycle at vaginal opening) and the ovarian folliculogenesis of immature female rats were evaluated. The choice of these parameters was not only guided by the influence of the gonadotrophic hormones (FSH, LH, PMSG, GnRH) on the precocious onset of puberty and the induction of the follicular growth in immature female rats, but also by the clinical usage of these hormones in the treatment of various forms of infertility (ovulatory defects or hypogonadal infertility) [34]. Puberty is the culmination of a complete sequence of maturational events that lead to the activation of the gonadotrophic axis, linked to the increase in serum levels of LH and FSH and attainment of sexual maturity. Estradiol has been reported to peak just before the

Table 1 Frequency (\%) of estrous cycle phases at vaginal opening in female rats treated with various doses of AESb

\begin{tabular}{llllll}
\hline & \multicolumn{3}{c}{ Cycle phases } & Total \\
\hline Doses & Proestrus & Esstrus & Metoestrus & Diestrus \\
\hline $\mathbf{0 ~} \mathbf{~ g} / \mathbf{k g}$ & 19.05 & 42.9 & 33.3 & 4.8 & 100 \\
\hline $\mathbf{8} \mathbf{~ m g} \mathbf{k g}$ & 23.1 & 46.2 & 7.7 & 23.1 & 100 \\
\hline $\mathbf{3 2} \mathbf{~ m g} \mathbf{k g}$ & 23.1 & 23.1 & 46.2 & 7.7 & 100 \\
\hline $\mathbf{6 4} \mathbf{~ m g} / \mathbf{k g}$ & 38.5 & 38.5 & 15.4 & 7.7 & 100 \\
\hline
\end{tabular}

(Fisher exact and Khi square tests). vaginal opening in female rats, showing that it is the effective molecule for puberty induction [35]. In various mammals, precocious puberty onset can be induced in a prepubertal animal by repeated injections of $\mathrm{GnRH}$, FSH, LH or of an analogous compound of a general excitatory neurotransmitter of the central nervous system, like glutamate or aspartate which induce the pulsatile releases of GnRH [36]. The pulsatile secretion of GnRH hormone at puberty leads to the pulsatile release of FSH and LH. These pituitary hormones in turn enhance the proliferation of the follicular cells and the production of estrogens (principally estradiol) by ovarian cholesterol catabolism [37]. The overall hormonal signalization culminates in the opening and cornification of the vagina, and to the increase in ovarian and uterine weight [38].

Oral administration of AESb for 30 days, at doses of 32 and $64 \mathrm{mg} / \mathrm{kg}$, to immature female rats led to a

Table 2 Effect of AESb on the duration (days) of the various phases in the estrous cycle

\begin{tabular}{llllll}
\hline Doses & \multicolumn{3}{l}{$\begin{array}{l}\text { Phases of the estrous } \\
\text { cycle }\end{array}$} \\
\cline { 2 - 6 } & Proestrus & Estrus & Metestrus & Diestrus & $\begin{array}{l}\text { Cycle } \\
\text { Length }\end{array}$ \\
\hline $0 \mathrm{mg} / \mathrm{kg}$ & $0.80 \pm 0.17$ & $1.38 \pm 0.19$ & $0.57 \pm 0.11$ & $1.22 \pm 0.16$ & $4.00 \pm 0.16$ \\
\hline $8 \mathrm{mg} / \mathrm{kg}$ & $0.56 \pm 0.10$ & $1.60 \pm 0.19$ & $0.57 \pm 0.12$ & $1.27 \pm 0.15$ & $4.00 \pm 0.11$ \\
\hline $32 \mathrm{mg} / \mathrm{kg}$ & $0.65 \pm 0.13$ & $1.58 \pm 0.24$ & $0.35 \pm 0.07$ & $1.42 \pm 0.17$ & $4.00 \pm 0.19$ \\
\hline $64 \mathrm{mg} / \mathrm{kg}$ & $0.75 \pm 0.17$ & $1.25 \pm 0.19$ & $0.73 \pm 0.14$ & $1.28 \pm 0.11$ & $4.01 \pm 0.15$ \\
\hline The length of the phases is expressed as days. Each value represents the mean \\
+ SEM for 13 animals
\end{tabular}




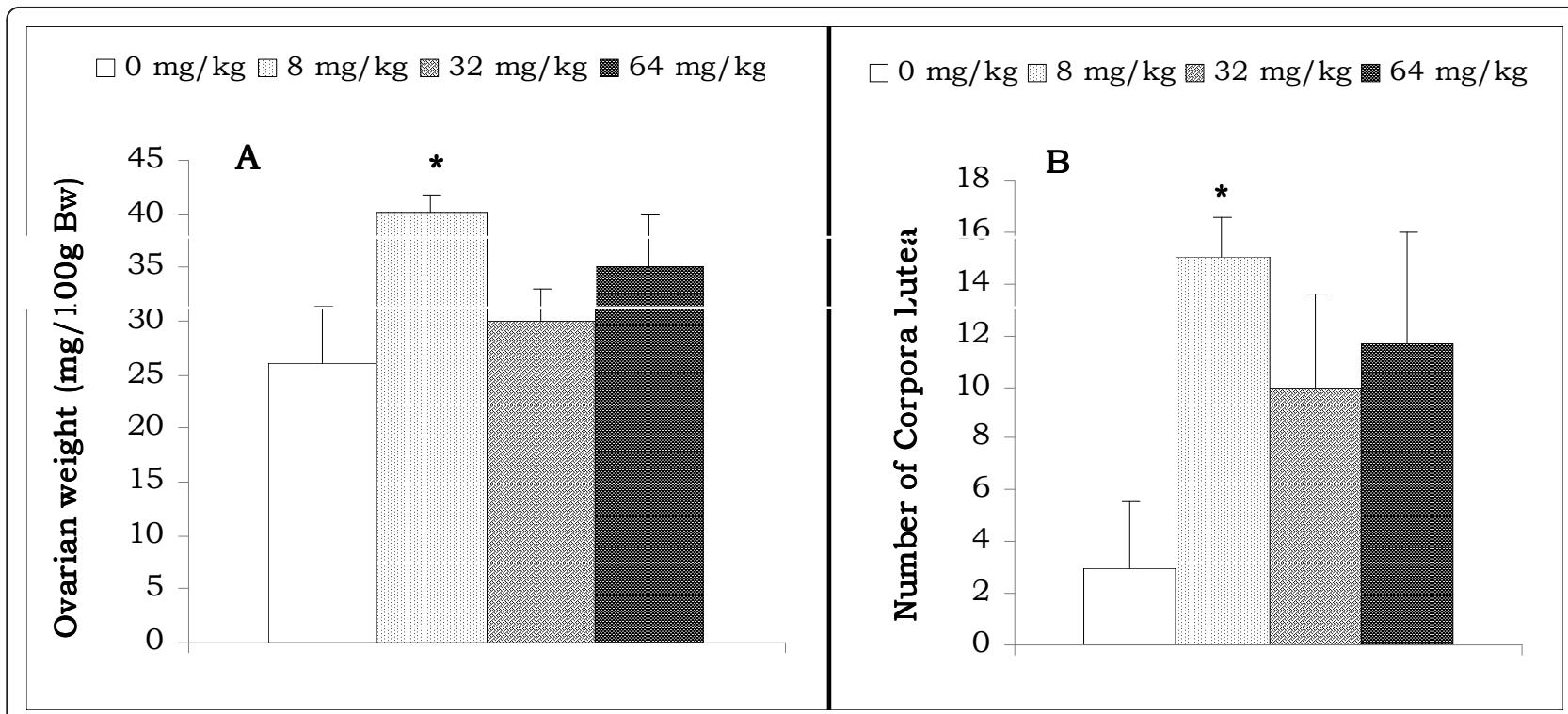

Figure 4 Effect of AESb on the relative weight of the ovaries (A) and the number of corpora lutea (B). *Values significantly different at ( $p$ $<0.05)$ from those of the control group (ANOVA and Fisher PLSD). Each histogram represents the mean \pm SEM of the values for 6 animals.

precocious onset of vaginal opening. This shows that the plant extract could contain molecules acting, as one of the above compounds, on the precocious onset of puberty. The same result was obtained, at $8 \mathrm{mg} / \mathrm{kg}$ dose, with the ethanolic extract of the plant [26]. This shows that the active compound of the plant would be more extracted by organic solvents.

The opening of the vagina on attainment of the pubertal age of rats resulted from the increase in the secretion of estrogens by ovarian follicles. The vaginal cells are also keratinized in this high estrogenic environment [39]. That is why the vaginal smear of pubertal rats the day of vaginal opening corresponds to the estrus phase of the cycle or to the nearest phase following it (metoestrus), as shown in Table 1. In animals treated with 8 and $32 \mathrm{mg} / \mathrm{kg}$ doses, the proestrus phase (preovulatory phase) was slightly reduced. This could be linked to the acceleration in the ovarian follicular

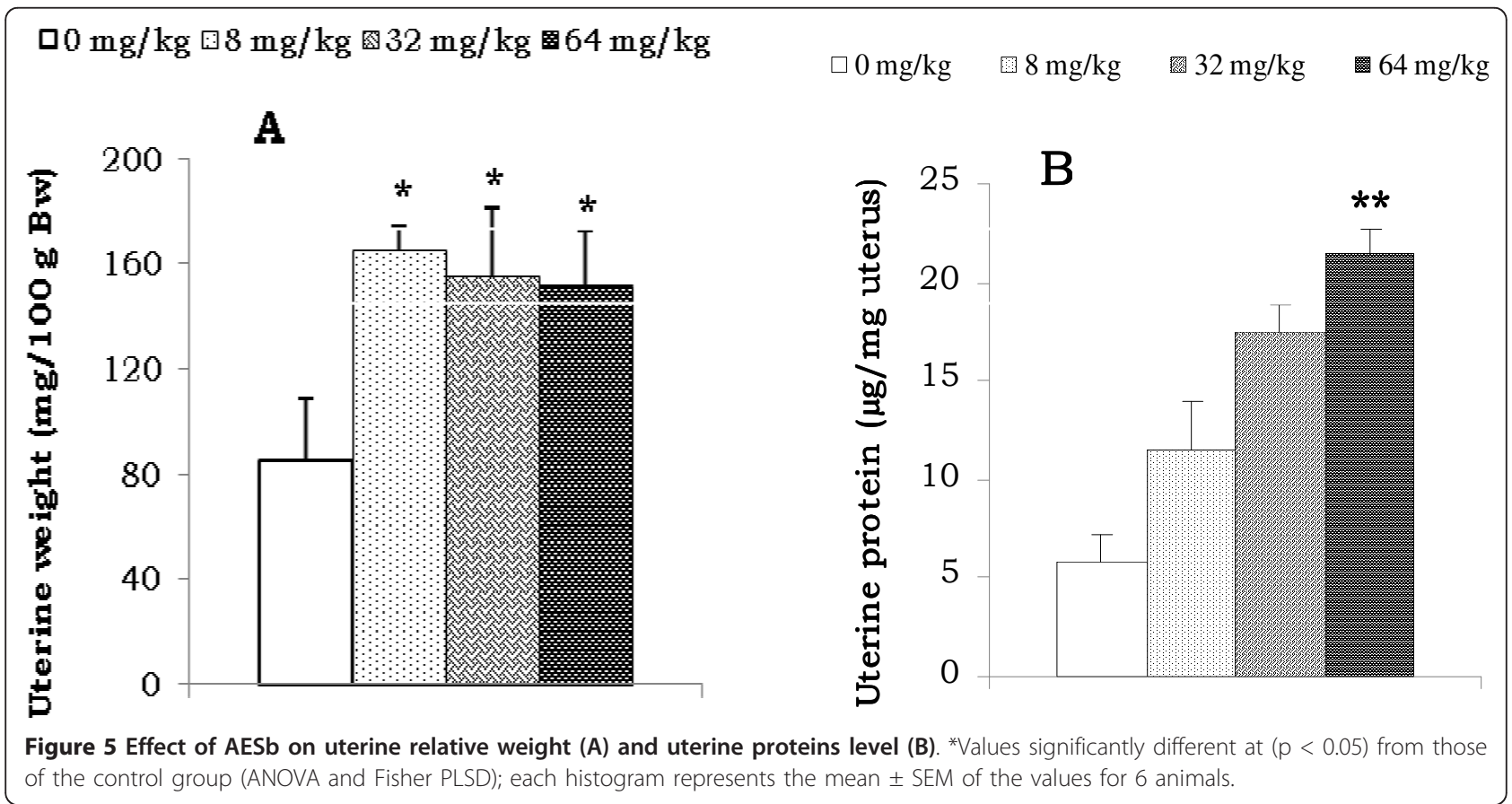


Table 3 Effect of AESb on some fertility and gestational parameters

\begin{tabular}{|c|c|c|c|c|}
\hline \multirow[t]{2}{*}{ Studied parameters } & \multicolumn{4}{|c|}{ Dosage (mg/kg/Day) } \\
\hline & $\overline{0}$ & 8 & 32 & 64 \\
\hline $\mathrm{N}^{\circ} \mathrm{C}$ rpora Lutea & $11.9 \pm 0.31$ & $11.57 \pm 0.61$ & $11.43 \pm 0.90$ & $10.33 \pm 1.50$ \\
\hline Nomplantation sites & $10.80 \pm 0.44$ & $10.43 \pm 0.57$ & $10.43 \pm 0.75$ & $9.00 \pm 1.48$ \\
\hline $\mathrm{N}^{\circ}$ Fetuses Alive & $9.50 \pm 0.50$ & $9.29 \pm 0.52$ & $9.86 \pm 0.77$ & $7.83 \pm 1.68$ \\
\hline $\mathrm{N}^{\circ}$ Resorption sites & $1.30 \pm 0.47$ & $1.00 \pm 0.44$ & $0.57 \pm 0.43$ & $1.17 \pm 0.48$ \\
\hline Mean weight of fetuses $(\mathrm{g})$ & $4.87 \pm 0.09$ & $5.16 \pm 0.17$ & $5.24 \pm 0.28$ & $5.27 \pm 0.13$ \\
\hline Fixation rate (\%) & $90.93 \pm 3.36$ & $91.10 \pm 5.15$ & $91.77 \pm 1.72$ & $84.58 \pm 5.06$ \\
\hline Preimplantation Loss (\%) & $9.07 \pm 3.36$ & $8.90 \pm 5.15$ & $8.23 \pm 1.72$ & $15.42 \pm 5.06$ \\
\hline Postimplantation Loss (\%) & $0.12 \pm 0.04$ & $0.11 \pm 0.04$ & $0.05 \pm 0.04$ & $0.25 \pm 0.16$ \\
\hline Antiimplantation Activity (\%) & 0 & 0 & 0 & 14.29 \\
\hline Antifertility Activity (\%) & 0 & 0 & 0 & 28.57 \\
\hline Resorption Index (\%) & 12.037 & 9.589 & 5.480 & 12.963 \\
\hline Gestation Rate (\%) & 100 & 100 & 100 & 85.71 \\
\hline
\end{tabular}

Each value represents the mean \pm SEM for 7 animals.

growth, given the high estrogenic environment of the ovarian cells, following the induction of pulsatile secretion of GnRH and gonadotrophins by AESb.

A significant reduction in the body weight gain of animals, after three weeks of oral administration of AESB, was also noticed. During the same period of treatment, no significant changes in various biochemical parameters of toxicity (data not shown) nor in the daily food intake of AESB treated animals was observed. Thus, this body weight reduction may be related to the cumulated slight decrease, during the same period of treatment, in food intake of those treated with the doses of 32 or 64 $\mathrm{mg} / \mathrm{kg}$ of AESB.

Estrogens and estrogen-like compounds (phytoestrogens) are well known regulators of growth and differentiation in a number of tissues. They exert their biological effect following their fixation to the receptors in their main target organs (ovary, uterus, hypothalamus, bone,...) thus leading to a chain of reactions, culminating in the biosynthesis of biomacromolecules (DNA, RNA, and proteins) and the increase in the weight of these organs, principally the ovary and uterus $[1,40,41]$. This weight increase is a combination of hypertrophic response of tissues following cell proliferative activities and water imbibition in the tissue [42]. The data on uterine parameters presented in this study has shown an increase of more than $96 \%$ and $87 \%$ in uterine proteins and uterine weight respectively, at all the doses. This increase in uterine proteins and weight may have resulted not only from the uterine cell proliferation induced by the oestrogenic effects of some chemical components of AESB but also from the increase in their water imbibition effect, especially at low dosage, in these cells. This estrogenic potential of AESB is also attested with the increase, at the dose of $8 \mathrm{mg} / \mathrm{kg}$, in ovarian weight and corpora lutea number.

As concerns the test on gestational parameters, a slight reduction in the number of corpora lutea, and gestational rate with the highest dose $(64 \mathrm{mg} / \mathrm{kg})$ could be linked to the reduction in the ovulation rate of these animals following the negative feed-back effect, at the level of the hypothalamus, of high estrogen level induced by this dose of the extract [37]. This could also results from the fact that estrogenic compounds cause contraction in the uterine smooth muscle, which could lead to the resorption of the fetus after its implantation [43].

\section{Conclusion}

Globally, this study has proven the implication of some compounds present in AESb on the rapid maturation of ovarian follicular cells leading to a precocious puberty onset. The mechanisms of this stimulation are multiple (induction of $\mathrm{GnRH}$ synthesis or secretion, induction of gonadotrophin synthesis or secretion, effects of estrogens-like compounds or specific amino acids present in the extract). Further studies are required for the elucidation of these mechanisms.

These results also corroborate with those obtained with the ethanolic extract of $S$. biafrae, but with different dosages. Thus, AESb would be less active than the ethanolic extract of the plant in inducing precocious puberty in immature female rats, but more safer for gestation. The therapeutic dose used by traditional medicine practitioners is able to stimulate folliculogenesis, but have a little effect on the maturation of the reproductive axis; for a better effect, this therapeutic dose should be increased. Unfortunately, high doses after 30 
days of treatment exhibit adverse effects on gestational parameters. So, the length of the treatment with these doses should be shortened.

\author{
Abbreviations \\ AESb: Aqueous extract of Senecio biafrae; GnRH: Gonadotropin Releasing \\ Hormone; LH: Luteinizing Hormone; FSH: Follicle Stimulating Hormone; \\ PMSG: Pregnant Mare Serum Gonadotropin; DNA: DeoxyriboNucleic Acid; \\ RNA: RiboNucleic Acid; STI: Sexually Transmitted Infections; ARTs: Assisted \\ Reproductive Technologies; WHO: World Health Organization.
}

\section{Acknowledgements}

Special thanks are due to the traditional healers who shared their knowledge with us.

\section{Author details}

'University of Dschang, Faculty of Science, Department of Biochemistry, P.O Box: 67 Dschang, Cameroon. ${ }^{2}$ University of Ouagadougou, UFR/SVT, Laboratory of Animal Physiology, 03 P.O. Box 7021, Ouagadougou 03 Burkina Faso, Africa. ${ }^{3}$ University of Yaounde I, Faculty of Science, Department of Biochemistry, P.O Box: 812, Yaounde, Cameroon.

\section{Authors' contributions}

LLL, TSR and YMD collected the samples, prepared the extract and carried out all the animal model experiments. GSC, MC and LMC participated to the study design and the statistical analysis or interpretation of the data. BBR helped in manuscript drafting, discussion and revision. TPB and MFP supervised, evaluated the data and corrected the manuscript for publication. All authors read and approved the final manuscript.

\section{Competing interests}

The authors declare that they have no competing interests.

Received: 18 October 2011 Accepted: 6 April 2012

Published: 6 April 2012

\section{References}

1. Müller JC, Giuliana GK, Botelho Aedra CB, Boareto CA, Rattmann DY, Martins ES, Cabrini DA, Otuki MF, Paulo RD: Morinda citrifolia Linn (Noni): In vivo and in vitro reproductive toxicology. I Ethnopharmacol 2009, 121:229-233.

2. Ates DA, Erdogrul OT: Antimicrobial activities of various medicinal and commercial plant extracts. Turk J Biol 2003, 27:157-162.

3. Edirne T, Arica SG, Gucuk S, Yildhizan R, Kolusari A, Adali E, Can M: Use of complementary and alternative medicines by a sample of Turkish women for infertility enhancement: a descriptive study. J Altern Complement Med 2010, 10:11.

4. Lux A: Le problème de la stérilité en Afrique et ses implications de politique démographique. Rev Canad Etud Afric 1976, 10:143-155.

5. Lienou LL, Telefo PB, Bayala BR, Yemele MD, Lemfack MC, Mouokeu C, Goka CS, Tagne SR, Moundipa FP: Ethnopharmacological survey of plants used for the treatment of female infertility in Baham, Cameroon. J Ethnopharmacol 2010, 136:178-187.

6. Adebooye OC: Solanecio biafrae (Oliv. \& Hiern) C.Jeffrey.Edited by: Grubben GJH, Denton OA. PROTA, Wageningen, Netherlands; 2004:, PROTA 2: Vegetables/Légumes. [CD-Rom].

7. Dairo FAS, Adanlawo IG: Nutritional Quality of Crassocephalum crepidioides and Senecio biafrae. Pakist I Nutri 2007, 6:35-39.

8. Tabopda TK, Fotso GW, Ngoupayo J, Mitaine-Offer AC, Ngadjui BT, LacailleDubois MA: Antimicrobial dihydroisocoumarins from Crassocephalum biafrae. Plant Med 2009, 75:1258-1261.

9. Adebayo AG: Inventory of antidiabetic plants in selected districts of Lagos State, Nigeria. J Ethnopharmacol 2009, 121:135-139.

10. Burkill HM: The useful plants of west tropical Africa. royal Botanic Garden K.E.W. 2 1985:1:960.

11. Iwu MM: Handbook of Africa medicinal plants. C.R.C. Press Boca Raton. Ann Arbor Florida USA; 1993, 435.

12. Focho DA, Nkeng EAP, Lucha CF, Ndam WT, Afegenui A: Ethnobotanical survey of plants used to treat diseases of the reproductive system and preliminary phytochemical screening of some species of malvaceae in Ndop Central Sub-division, Cameroon. J Medic Plant Res 2009, 3:301-314.

13. Daar AS, Merali Z: Infertility and social suffering: the case of ART in developing countries. In Current practices and controversies in assisted reproduction Report of a meeting on "Medical, ethical and social aspects of assisted reproduction". Edited by: Vayena E, Rowe PJ, Griffin PD. Geneva, Switzerland: World Health Organization; 2002:15-21.

14. Larsen SH, Wagner G, Heitmann BL: Sexual function and obesity. Inter J Obesity 2007, 31:1189-1198.

15. Breart G, De Mouzon J: AMP vigilance. Bullet Acad Nat Méd 1995, 179:1759-1764

16. Chopra R, Nayyar SL, Chopra IC: Indian Medicinal Plants CSIR: New Delhi. J Ethnopharmacol 2006, 106:425-428.

17. Moundipa FP, Kamtchouing P, Koueta N, Mbiapo F, Tantchou J: Effects of aqueous extract of Hibiscus macranthus and Basela alba Linn. In immature rat testis function. 1993, Andrology in the nineties (Book of abstracts). International symposium on male infertility and assisted reproduction. April 21-24, Gent, Belgium.

18. Al-Qarawi AA, Abdel-Rahman HA, El-Badry AA, Harraz F, Razig NA, AbdelMagied EM: The effect of extracts of Cynomorium coccineum and Withania somnifera on gonadotrophins and ovarian follicles of immature rats. Phytother Res 2000, 14:288-290.

19. Telefo PB, Moundipa PF, Tchana AF, Tchouanguep DC, Mbiapo FT: Effects of an aqueous extract of Aloe buettneri, Dicliptera verticillata, Hibiscus macranthus, and Justicia insularis on some biochemical and physiological parameters of reproduction in immature female rat. $J$ Ethnopharmacol 1998, 63:193-200.

20. Telefo PB, Moundipa PF, Tchouanguep FM: Inductive effects of the leaf mixture extract of Aloe buettneri, Justicia insularis, Dicliptera verticillata and Hibicus marcranthus on in vitro production of oestradiol. J Ethnopharmacol 2004, 90:225-230.

21. Jha U, Asad M, Asdaq BMS, Das KA, Satya Prasad SV: Fertility inducing effect of aerial parts of Coccinia cordifolia L. in female rats. J Ethnopharmacol 2010, 127:561-564.

22. Knudsen JF, Mahesh VB: Initiation of precocious maturation in the immature rat treated with dehydroepiandrosterone. Endocrinology 1975, 97:458-468.

23. Tohei A, Sakamoto S, Kogo H: Dexamethasone or Triamcinolone increases follicular development in immature female rats. Japan J Pharmacol 2000, 84:281-286.

24. Srivasta K, Dasgupta PK: Mode of action of centchroman at vaginal and ovarian level in immature rats. India J Physiol Pharmacol 1980, 24:43-48.

25. Butterstein GM, Schladler MH, Lysogorski E, Robin L, Sipperly S: A Naturally occurring plant compound, 6-Methoxybenzoxazolinone, stimulates reproductive responses in rats. Biol Reprod 1985, 32:1018-1023.

26. Lienou LL, Telefo PB, Bayala B, Yemele MD, Lemfack MC, Mouokeu C, Goka CS, Tagne SR, Moundipa FP: Effect of ethanolic extract of Senecio biafrae on puberty onset and fertility in immature female rat. Cam J Experiment Biol 2010, 06:101-109.

27. EEC: Council Directive $86 / 609 / \mathrm{EEC}$ of 24 November 1986 on the approximation of laws, regulations and administrative provisions of the Member States regarding the protection of animals used for experimental and other scientific purposes. Offical Journal of the European Communities 1986, L358:1-29.

28. Costa-Silva JH, Lyra MMA, Lima CR, Arruda VM, Araújo AV, Ribeiro E, Ribeiro A, Arruda AC, Fraga MCCA, Lafayette SSL, Wanderley AG: A toxicology evaluation of the effect of Carapa guianensis Aublet on pregnancy in Wistar rats. J Ethnopharmacol 2007, 116:495-500.

29. Bradford MM: A rapid and sensitive method for the quantification of microgram quantities of protein utilizing the principle of protein-dye binding. Anal Biochem 1976, 72:248-254.

30. Trinder P: Determination of glucose in blood using glucose oxidase with alternative oxygen acceptor. Ann Clin Biochem 1969, 6:24-27.

31. Richmond W: Preparation and properties of cholesterol oxidase from Ocurdia Sp, And its application to enzymatic assay of total cholesterol in serum. Clin Chem 1973, 19:1350-1356.

32. Roeschlau: Enzymatic determination of total cholesterol in serum. Euro J Clin Chem Clin Biochem 1974, 12.

33. Schwartz D: Méthodes statistiques à l'usage des médecins et des biologistes. Flammarion, Médecine, Sciences, Paris; 3 1991, 306. 
34. La Rochebrochard L: Médicalisation de l'infertilité: quelle est la situation mondiale du nord au sud? INED-INSERM, Kremlin-Bicêtre (94), France; 2004

35. Ojeda SR, Urbanski HF: Puberty in the rat.Edited by: Knobil E, Neill J. et al. The physiology of reproduction Raven press, Ltd., New York; 1988:39:1699-1737.

36. Nicolino M, Forest GM: La puberté. In La reproduction chez les mammifères et l'homme. Volume 29. Edited by: Thibault C, Levasseur MC. INRA, Ellipses paris; 2001:655-679.

37. Skibola CF: The effect of Fucus vesiculosus, an edible brown seaweed, upon menstrual cycle length and hormonal status in three premenopausal women: a case report. J Altern Complement Med 2004, 4:10.

38. Counis $R$, Combarnous $Y$, Chabot $V$, Taragnat $C$ : Régulation de la synthèse et de la libération des gonadotropines hypophysaires. In La reproduction chez les mammiferes et l'homme. Volume 3. Edited by: Thibault C, Levasseur MC. INRA, Ellipses paris; 2001:65-84.

39. Navarro VM, Fernandez-Fernandez R, Castellano JM, Roa J, Mayen A Barreiro ML, Gaytan F, Aguilar E, Pinilla L, Dieguez C, Tena-Sempere M: Advanced vaginal opening by precocious activation of the reproductive axis by KISS-1 peptide, the endogenous ligand of GPR54. J Physiol Soc 2004, 561:379-386.

40. Jensen EV, Desombre ER: Mechanism of action of the female sex hormones. Ann Rev Biochem 1972, 41:203-230.

41. Katzenellenbogen BS, Bhakoo HS, Ferguson ER, Lan HC, Tatee T, Tsia TLS, Katzenellenbogen JA: Estrogen and anti estrogen action in reproductive tissues and tumors. Rec Prog Horm Res 1979, 35:259-292.

42. Jablonski EM, McConnell NA, Hughes FM Jr, Huet-Hudson YM: Estrogen regulation of aquaporins in the mouse uterus: potential roles in uterine water movement. Biol Reprod 2003, 69:1481-1487.

43. Ford WCL: The effect of deoxy-6-fluoroglucose on the fertility of male rats and mice. Contraception 1982, 25:535-545.

\section{Pre-publication history}

The pre-publication history for this paper can be accessed here: http://www.biomedcentral.com/1472-6882/12/36/prepub

doi:10.1186/1472-6882-12-36

Cite this article as: Lienou et al.: Effect of the aqueous extract of Senecio biafrae (Oliv. \& Hiern) J. Moore on sexual maturation of immature female rat. BMC Complementary and Alternative Medicine 2012 12:36.

\section{Submit your next manuscript to BioMed Central and take full advantage of:}

- Convenient online submission

- Thorough peer review

- No space constraints or color figure charges

- Immediate publication on acceptance

- Inclusion in PubMed, CAS, Scopus and Google Scholar

- Research which is freely available for redistribution

Submit your manuscript at www.biomedcentral.com/submit 